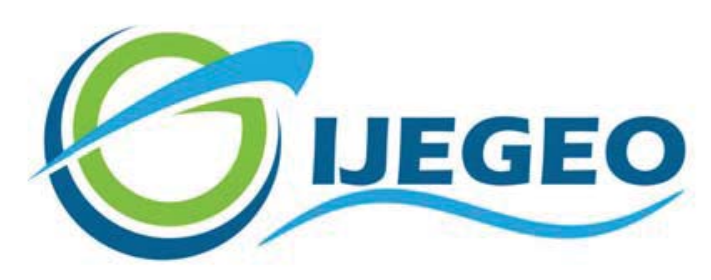

International Journal of Environment and Geoinformatics (IJEGEO) is an international, multidisciplinary, peer reviewed, open access journal.

\title{
Vessel Traffic Characteristics Analysis on the Cross-section of the 1915 Çanakkale Bridge at the Strait of Çanakkale
}

\section{Burak KUNDAKCI, Selçuk NAS}

\author{
Chief in Editor \\ Prof. Dr. Cem Gazioğlu \\ Co-Editors Prof. Dr. Dursun Zafer Şeker, Prof. Dr. Şinasi Kaya, \\ Prof. Dr. Ayşegül Tanık and Assist. Prof. Dr. Volkan Demir
}

Editorial Committee (June 2022)

Assoc. Prof. Dr. Abdullah Aksu (TR), Assoc. Prof. Dr. Uğur Algancı (TR), Assoc. Prof. Dr. Aslı Aslan (US), Prof. Dr. Levent Bat (TR), Prof. Dr. Paul Bates (UK), İrşad Bayırhan (TR), Prof. Dr. Bülent

Bayram (TR), Prof. Dr. Luis M. Botana (ES), Prof. Dr. Nuray Çağlar (TR), Prof. Dr. Sukanta Dash (IN), Dr. Soofia T. Elias (UK), Prof. Dr. A. Evren Erginal (TR), Assoc. Prof. Dr. Cüneyt Erenoğlu (TR), Dr. Dieter Fritsch (DE), Prof. Dr. Ç; Prof. Dr. Manik Kalubarme (IN), Dr. Hakan Kaya (TR), Assist. Prof. Dr. Serkan Kükrer (TR), Assoc. Prof. Dr. Maged Marghany (MY); Prof. Dr. Micheal Meadows (ZA), Prof. Dr. Nebiye Musaoğlu (TR), Prof. Dr. Masafumi Nakagawa (JP), Prof. Dr. Hasan Özdemir (TR), Prof. Dr. Chyssy Potsiou (GR), Prof. Dr. Erol Sarı (TR), Prof. Dr. Maria Paradiso (IT), Prof. Dr. Petros Patias (GR), Prof. Dr. Elif Sertel (TR), Prof. Dr. Nüket Sivri (TR), Prof. Dr. Füsun Balık Şanlı (TR), Dr. Duygu Ülker (TR), Prof. Dr. Seyfettin Tsaş (TR), Assoc. Prof. Dr. Ömer Suat Taşkın (TR), Assist. Prof. Dr. Tuba Ünsal (TR), Assist. Prof. Dr. Sibel Zeki (TR) 
Research Article

\title{
Vessel Traffic Characteristics Analysis on the Cross-section of the 1915 Çanakkale Bridge at the Strait of Çanakkale
}

\author{
Burak Kundakçı ${ }^{1,2 *}$ (D), Selçuk Nas ${ }^{3}$ (D) \\ ${ }^{1}$ Department of Marine Transportation Engineering, Maritime Faculty, Dokuz Eylül University, İzmir, Turkey \\ ${ }^{2}$ Department of Marine Transportation Engineering, Barbaros Hayrettin Naval Architecture and Maritime Faculty, İskenderun Technical University, \\ Hatay, Turkey \\ ${ }^{3}$ Department of Maritime Education, Maritime Faculty, Dokuz Eylül University, İzmir, Turkey
}

* Corresponding author: B. Kundakçı

Received 30.07.2021

*E-mail: bkkundakci@gmail.com

Accepted 16.10.2021

How to cite: Kundakçı and Nas (2021). Vessel Traffic Characteristics Analysis on the Cross-section of the 1915 Çanakkale Bridge at the Strait of Çanakkale. International Journal of Environment and Geoinformatics (IJEGEO), 9(2): 060-070. doi. 10.30897/ijegeo.976490

\begin{abstract}
The 1915 Çanakkale Bridge is being built on two main towers using the suspension bridge technique. It is seen that the Europe Tower is located within the southern separation scheme and the Asia Tower is located outside the northern separation scheme. The main purpose of this study is to analyse the existing marine traffic on the cross-sectional line where the bridge towers are located and the possible effects of the bridge towers on the marine traffic. For these analyses Automatic Identification System (AIS) data of 2016 and the software program which was developed with intersection algorithm has been used. In the analyses, the axis of the bridge towers on the sea has been taken as a cross-section and divided into slots of 50 meters each. The ship distribution on the crosssectional line and relation of the vessel size and the preferred slots by the ships have been revealed.
\end{abstract}

Keywords: 1915 Çanakkale Bridge, Marine Traffic, Marine Traffic Analysis, Intersection Algorithm

\section{Introduction}

Automatic Identification System (AIS) is a system where ships instantly transmit such information as position and speed to the nearby ships and the coast stations. With this information, the movements of the ships can be monitored both by the ships and the coast stations, and it is also possible to store these data by the coast stations and then to use the stored historical data to make various analyses of the marine traffic.

There are many studies on highly detailed AIS data. While in some studies these data are used to map the global shipping density (L. Wu et al., 2017) in some other studies they are used to map or analyse the regional marine traffic (Mustaffa et al., 2015) or fishing vessel traffic (Natale et al., 2015) or only statistical analyses have been carried out (Mustaffa et al., 2016). AIS data are also used to make comparison about the ship behaviours in narrow waterway and wide waterway (Xiao et al., 2015). These data may also be used to analyse the influence of external conditions and vessel behaviours (Shu et al., 2017). They are also used for the vessel traffic stream analysis under the Great Belt Bridge (Marcjan et al., 2013). Various analyses on waterways (X. Wu et al., 2016) and straits (Chen et al., 2015) (Kang et al., 2018) have been carried out using AIS data by various researchers. To investigate the traffic distribution in Northern Aegean Sea, an algorithm has been developed by (Kundakç1 and Nas, 2018). In the developed algorithm, marine traffic data on a cross- section taken on a particular waterway have been analysed statistically.

AIS data can also be used to reveal the vessel traffic characteristics. That can be defined as Type Characteristics, Structure Characteristics and Behaviour Characteristics. The "type characteristics" involves such information as inland vessel traffic flow, coastal vessel traffic flow, tanker traffic flow and container ship traffic flow. The "structure characteristics" comprises such information as ship type, ship length, ship length distribution and representative values, ship designed draft distribution and representative values. The "behaviour characteristics" includes such information as ship speed, ship heading, spatial distribution of traffic flow, speed distribution and representative values. (Liu et al., 2017).

In this study, lateral distribution, SOG distribution, LOA distribution, vessel type's distribution and their relations with the seasons on the cross-section have been defined as vessel traffic characteristics. The motivation of this study is the need to analyse the marine traffic likely to be effected by the positioning of the towers of the 1915 Çanakkale Bridge, being built in the Strait of Çanakkale. The Strait of Çanakkale is a 37 NM long waterway between Aegean Sea and Marmara Sea + Black Sea and a very important waterway for the commercial vessels. The Strait of Çanakkale, a very busy area with two-way ship traffic, has been used by an average of 45.000 ships per year (URL1, 2019; Usluer et al., 2020). For these 
reasons, the possible impact of the 1915 Çanakkale Bridge, which is being built on the Strait of Çanakkale, should be scrutinized and thought over thoroughly. AIS data is very useful for conducting such scrutiny and investigation. There have been few studies carried out on the safety of marine traffic through the Strait of Çanakkale. Besides, there has been no study that uses AIS data to analyse the marine traffic in the Strait of Çanakkale. In the study conducted by (Ilgar, 2015) within the scope of marine traffic safety, the risk distribution map in Figure 1 has been created by taking into consideration the number of accidents encountered in the Strait of Çanakkale, the type of ships involved in the accidents, the location of the accidents, the meteorological characteristics of the Strait of Çanakkale and its surroundings, as well as the data of oceanographic and geomorphological surveys.

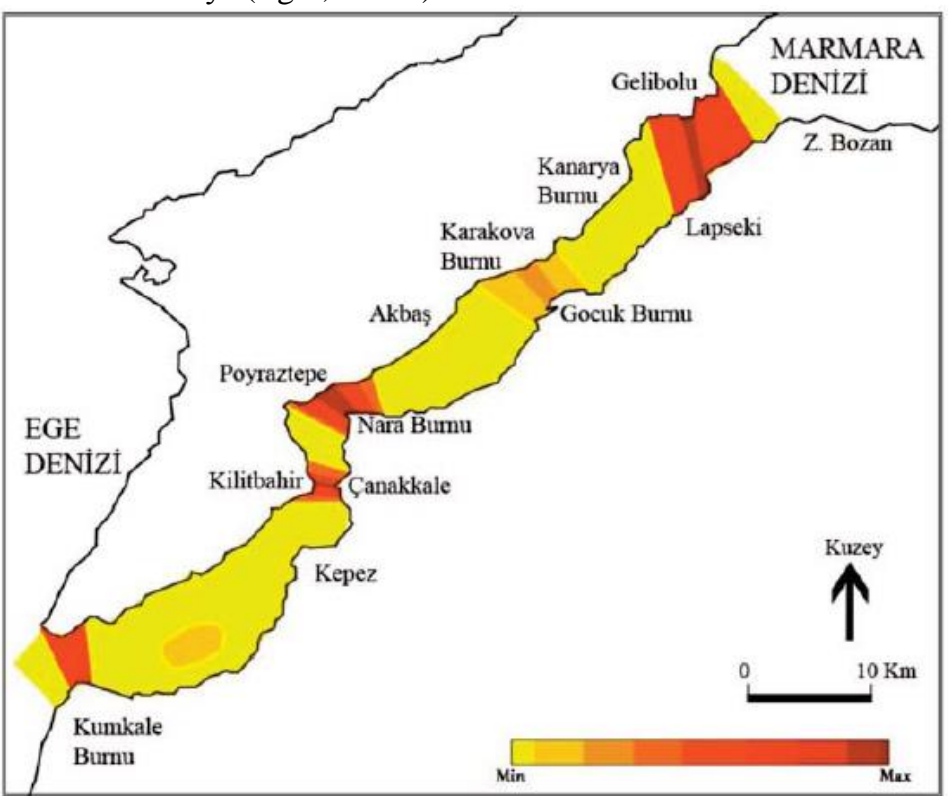

Fig. 1. The Strait of Çanakkale Marine Traffic Accident Risk Intensity Map (Ilgar, 2015)

According to this study, the riskiest areas for the collision in the Strait of Çanakkale are between Kilitbahir-Çanakkale and Nara Burnu-Poyraztepe. Lapseki and Gelibolu coasts are remains risk for grounding due to shallow areas. The area where the 1915 Çanakkale Bridge will be built is close to the Lapseki and Gelibolu regions. On the other hand, bridge area is shown as light yellow color and according to the Ilgar (2015), the areas shown in light yellow color on the map are the areas with the least accident risk where no accident has occurred so far. A similar study has been conducted by (Kuleyin and Aytekin, 2015). In this study the locations where the accidents took place between 2004 and 2014 in the Strait of Çanakkale are located on the map. It is seen that the most encountered accident type is grounding and most of these accidents occurred at the entrance of Kumkale. The most common cause of the accidents is the equipment failure. As a result of the analysis of the locations it is seen that the highest number of the accidents have taken place in the Nara.

Since the towers of the bridge will be built in the traffic separation of the Strait of Çanakkale, the area where the ships can navigate will be limited with the safe area between the towers of the bridge. However, in order to analyse the effects of this restriction on marine traffic, some calculations should be made.

\section{Methodology}

The aim of this study is to analyse vessel traffic characteristics on the Cross-sectional line of the 1915 Çanakkale Bridge at the Strait of Çanakkale. For this purpose, the marine traffic has been scrutinized by using static, dynamic and navigational information received from AIS devices and the ship distributions on the crosssectional line analyzed statistically. These statistical analyses involve lateral distribution, SOG distribution, LOA distribution, vessel types distribution and their relations with the seasons in scope of "the vessel traffic characteristics".

As ships move and alter courses, data are sent to the nearby ships, shore stations at varying intervals by the AIS device. The transmission intervals of this data may reduce to 2 seconds depending on the speed of the ship and whether it changes course (ITU-R, 2014). In order to analyse the movement of ships on certain lines, a crosssectional line should be determined and the intersection point of this line and ship movements should be calculated. In order to determine the line on which the section will be taken, it is necessary to map the marine traffic. In this study, the algorithms developed by Kundakçı and Nas (2018) and their software are used to transfer the movement of the ships to the map and to analyse the distribution of the ships on the designated cross-sectional line. The model of the study using the one-year AIS data for 2016 is indicated in Figure 2. In this study, 104,863,234 rows of one-year AIS data for 2016, divided into 19 columns, have been analyzed and the data set to be used in the analyses has been created by removing the missing and incorrect data. The total number of AIS data including such information as position, type, length of the vessels is 104,863,234 x 19 $=1,992,401,446\left(\sim 2 \times 10^{9}\right)$. 


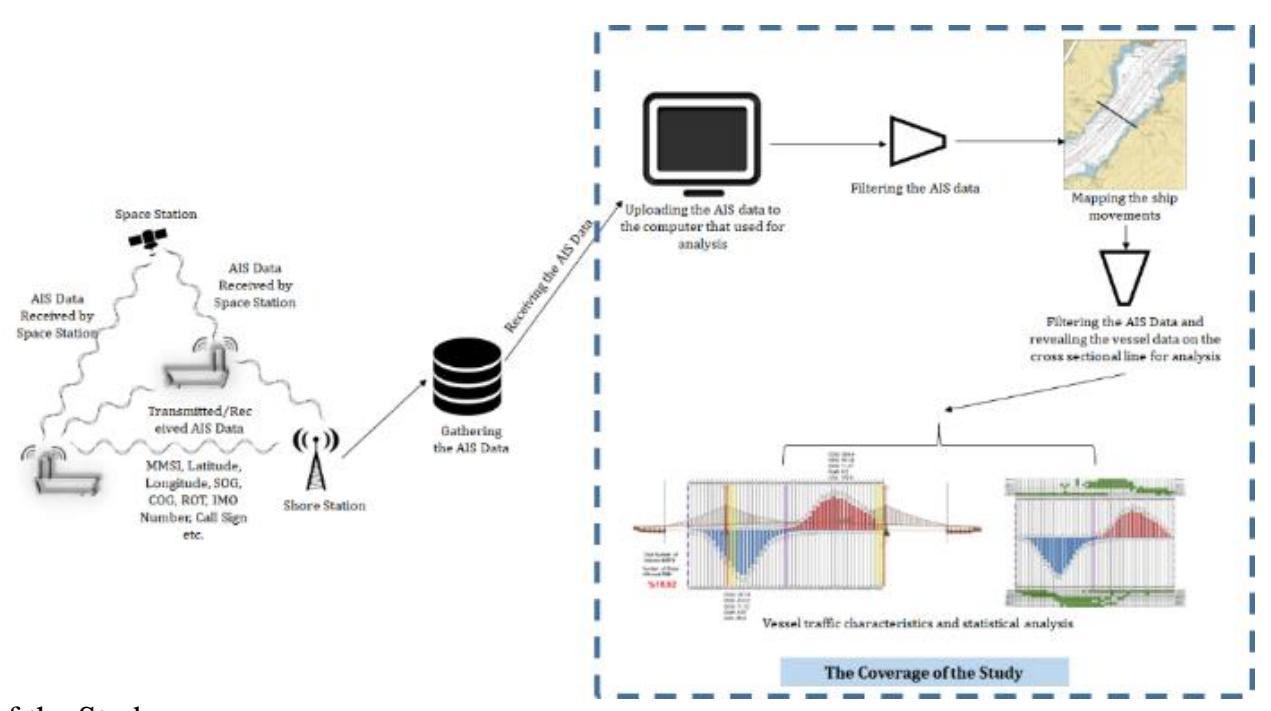

Fig. 2. Model of the Study

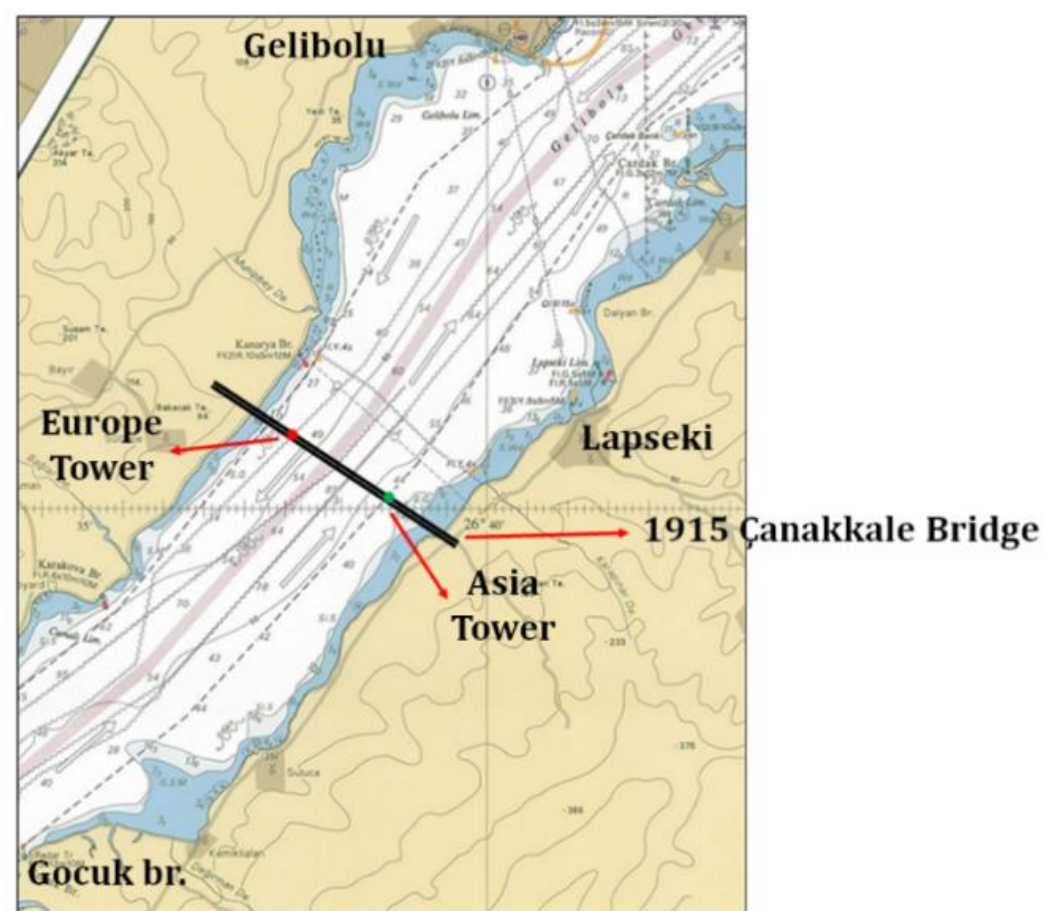

Fig. 3. The Strait of Çanakkale Map and the Section of the 1915 Çanakkale Bridge

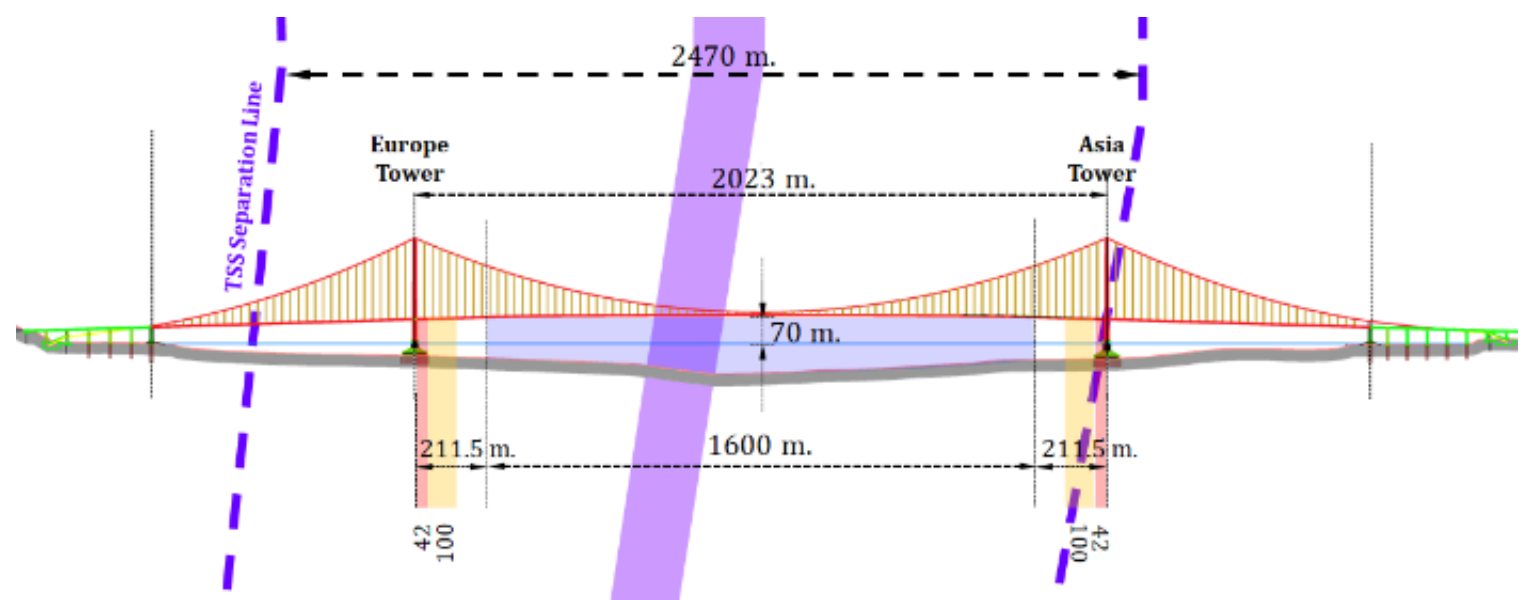

Fig. 4. Previous TSS Separation Lines and Dimensions of the 1915 Çanakkale Bridge (Zorba and Nas, 2019) 
Using this data, the ship movements according to the ship type are mapped with the help of the software program. Then the ship distributions are examined by taking cross-sections from the points on the traffic separation scheme in the section where the bridge will be constructed.

The map, which is shown the cross-sectional line of the 1915 Canakkale Bridge, used for the analyses of marine traffic is shown in Figure 3. The map covers the latitudes between $40.27^{\circ} \mathrm{N}-40.41^{\circ} \mathrm{N}$ and longitude between $026.57^{\circ} \mathrm{E}-026.72^{\circ} \mathrm{E}$.

Ship movements are coded with different colours and transferred to the map. After the ship movements are transferred to the map, the ship distributions are revealed using the intersection algorithm created by Antonio, (1992). The analyses have been carried out for ships considered to be dangerous for the bridge. Distributions of small-sized vessels such as fishing vessels have not separately been extracted, and they have been calculated under all types of vessels. The towers of the bridge, previous TSS separation lines and dimensions are shown in Figure 4.

The total width of the navigable area in the previous separation scheme was 2,470 meters. This width has been reduced to 1,600 meters with the start of the construction of the bridge as shown in Figure 4. The 1915 Çanakkale Bridge has a 1,600-meter clearance where the height is provided over a minimum of 70 meters from water. This clearance is greater than the calculated distance considering the PIANC maximum safety criteria for two-way traffic (Zorba \& Nas, 2019). According to the Istanbul Port Authority - Local Maritime Traffic Guide, distances of the ships to the bridge towers should be no less than 50 meters in the İstanbul Strait. According to the Izmit, Izmir, Mersin Vessel Traffic Services (VTS) Implementation Instruction, no ship, including local traffic, should navigate with the distance of less than 100 meters of the Osmangazi Bridge. In this study, as shown in Figure 4, 100 meters safe area is defined from the towers.

There are also some limitations in the study. The limits of the AIS data and the missing/incorrect data in the data set gathered by the shore stations are the limitations of the study.

\section{Findings}

First, one-year AIS data has been used to map the marine traffic density according to the ship types. Marine traffic density maps have been prepared on a monthly basis and annually and ship movements have been analyzed. As an example, the marine traffic density map of cargo vessels, tanker vessels, passenger vessels, tanker vessels with the lengths of 200 meters and above, vessels with the lengths of 300 meters and above and all types of vessels for January 2016 are shown in Figure 5.
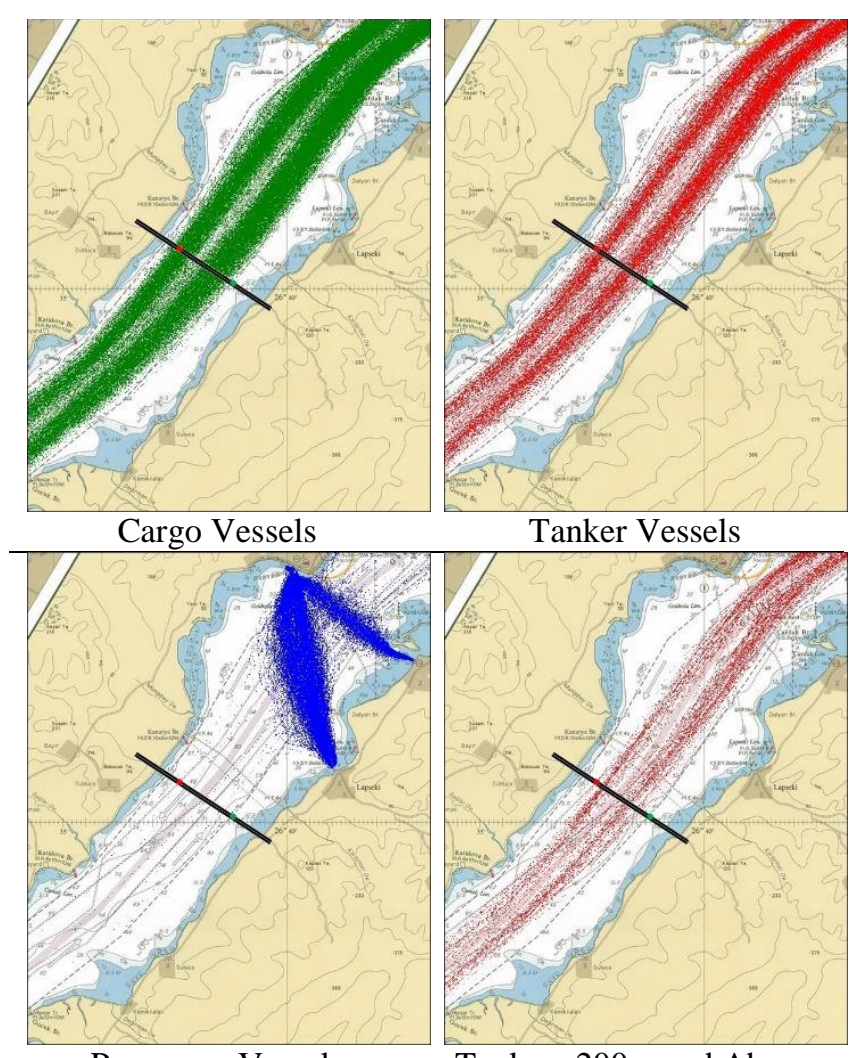

Tanker Vessels

Passenger Vessels

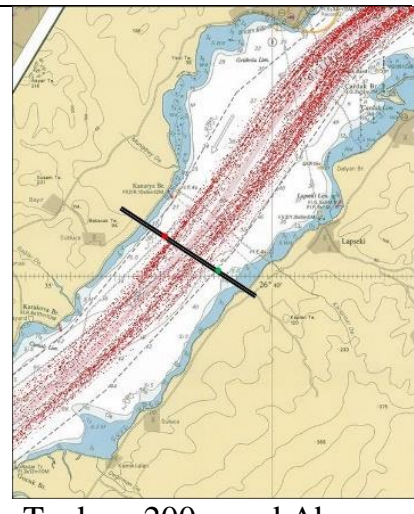

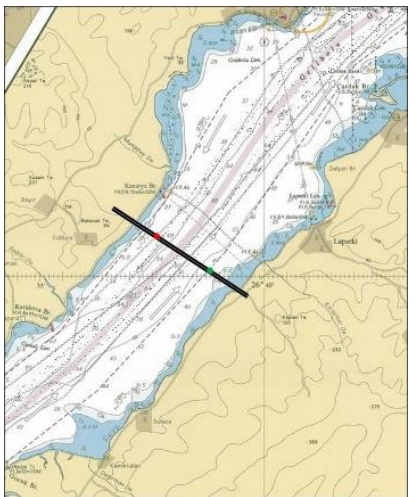

Vessels 300m and Above

\section{Tankers 200m and Above}

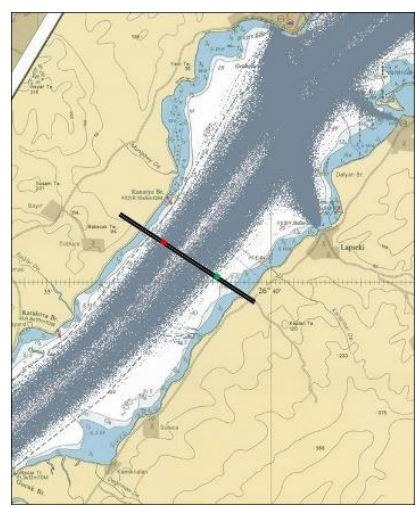

All Types of Vessels
Fig. 5. Marine Traffic Density Map for January 2016

When Figure 5 is examined, it is seen that ships tend to alter course with the small angles and marine traffic follows a linear route. In addition, it is observed that while the traffic separation scheme expands towards the Gulf of Gelibolu and North of Cape Gocuk, these expansions are not preferred by the ships.

After analyzing the density maps according to the ship types, the effect of the 1915 Çanakkale Bridge on the marine traffic has been analyzed separately according to the ship types by taking a cross-sectional line from the direction where the bridge towers are positioned. Both ends of the cross-section are taken from the traffic separation scheme which intersects with the bridge. In this way, the whole area where the current traffic can pass has been selected and the ships to be effected by the towers of the bridge have been revealed. The ship distributions have been divided into 50-meter slots. 


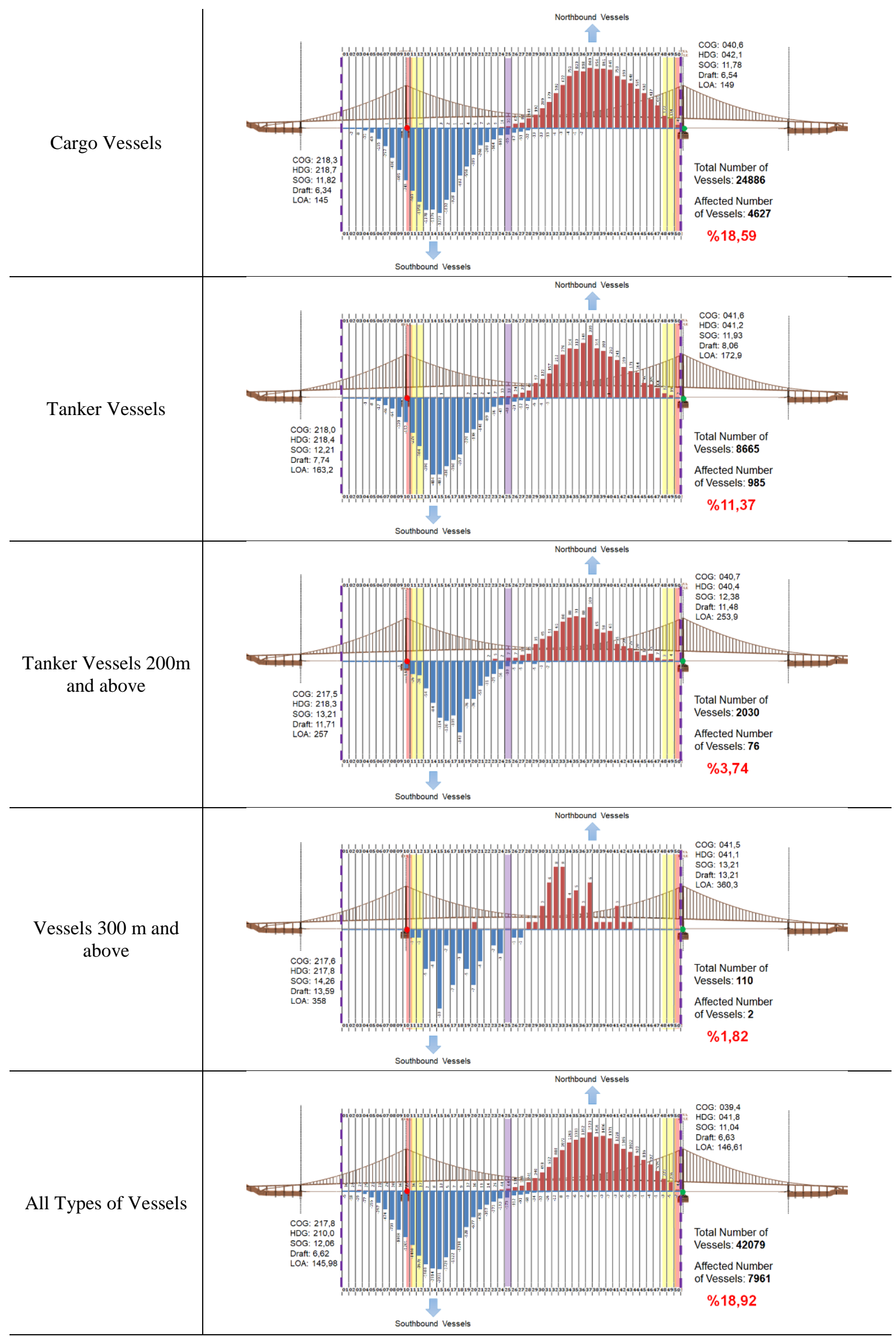

Fig. 6. Cross-Sectional Distribution of the Vessels on the 1915 Çanakkale Bridge 
According to Figure 7, it can be clearly seen that as the vessel SOG increases, the vessels tends to move towards the middle of the separation scheme. One of the reasons for this is the small size and slow vessels are using the starboard side of the appropriate traffic lane and the vessels with higher speeds are using the port side of the appropriate traffic lane to overtake those small size and slow vessels. To understand the relation between the SOG of the vessels and their preferred slots, Pearson Chi-square test has been carried out. According to the analysis, there is a significant relationship (Northbound traffic $X^{2}(196)=5931.810^{\mathrm{a}}, \mathrm{p}<0.001$ - Southbound traffic $\left.X^{2}(196)=4024.384^{a}, p<0.001\right)$ between ship SOG and preferred slots.

After visualizing the vessels according to the SOG, vessel distribution for different sizes have been visualized. Figure 8 shows the distribution of the vessels according to the LOA. The vessels have been grouped as 1-49 meters, 50-99 meters, 100-149 meters, 150-199 meters, 200-249 meters, 250-299 meters, 300-400 meters.

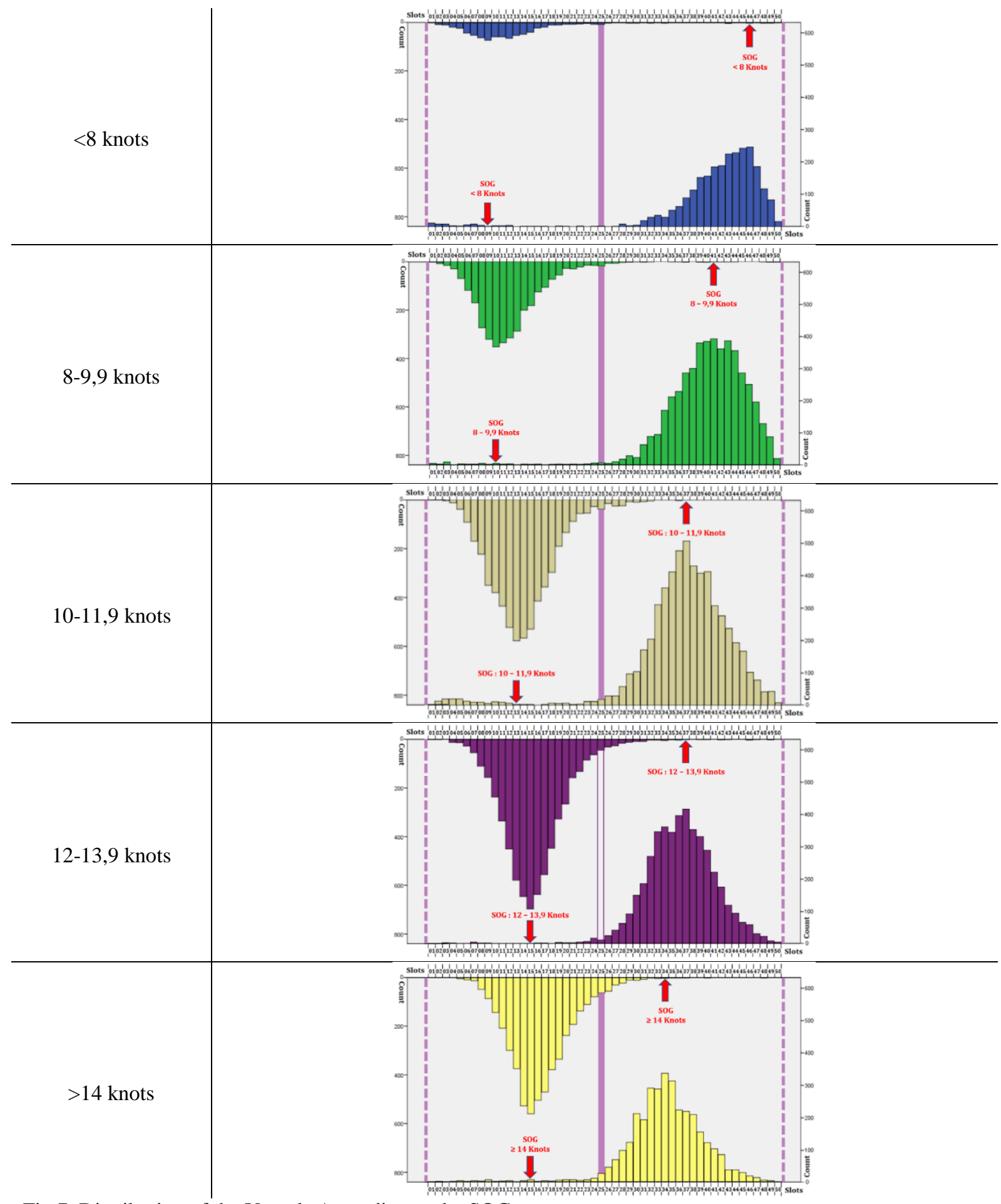

Fig 7. Distribution of the Vessels According to the SOG 


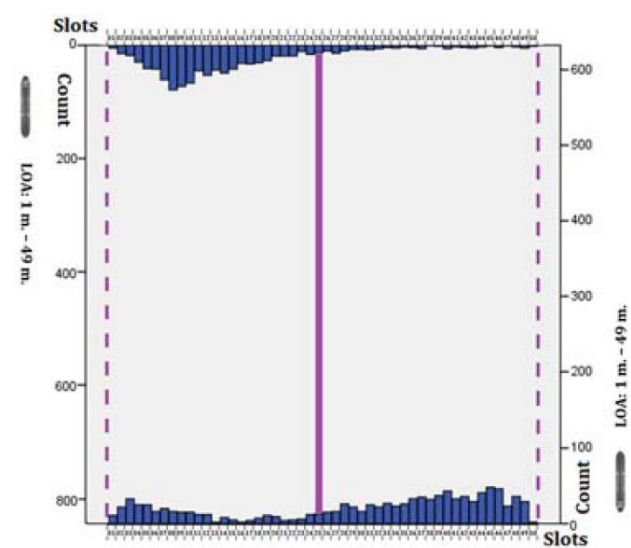

a) 1-49 meters

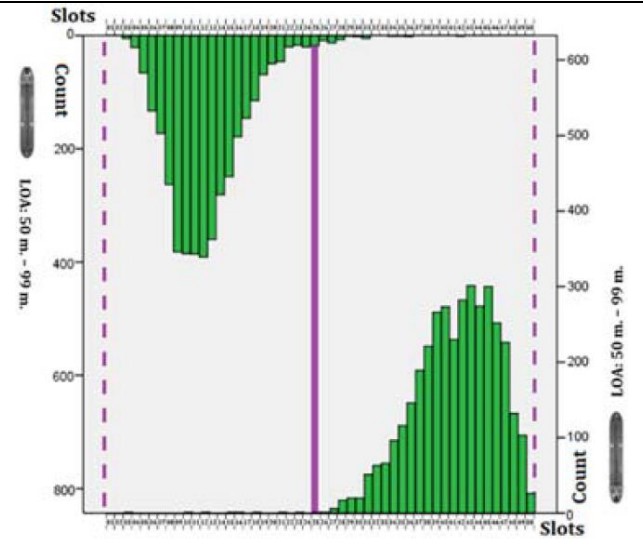

b) 50-99 meters

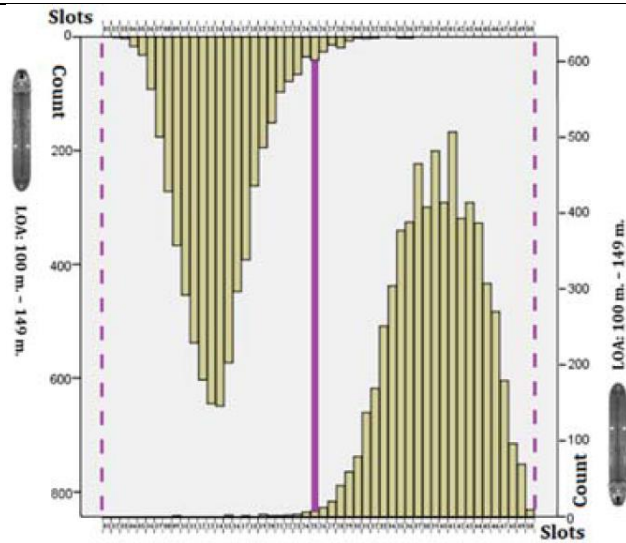

c) $100-149$ meters

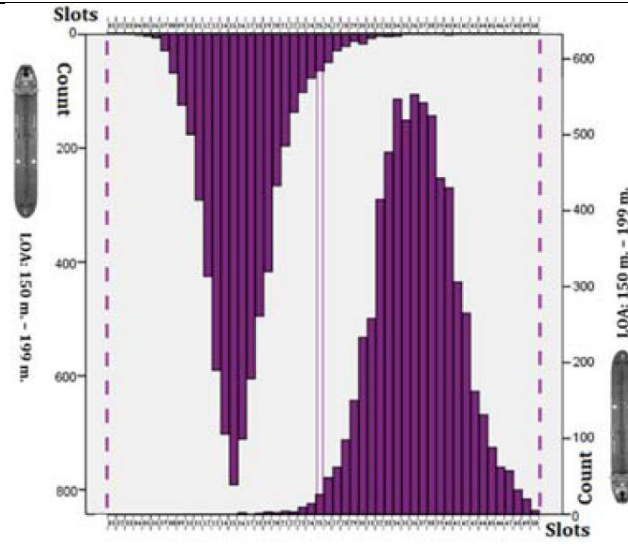

d) 150-199 meters

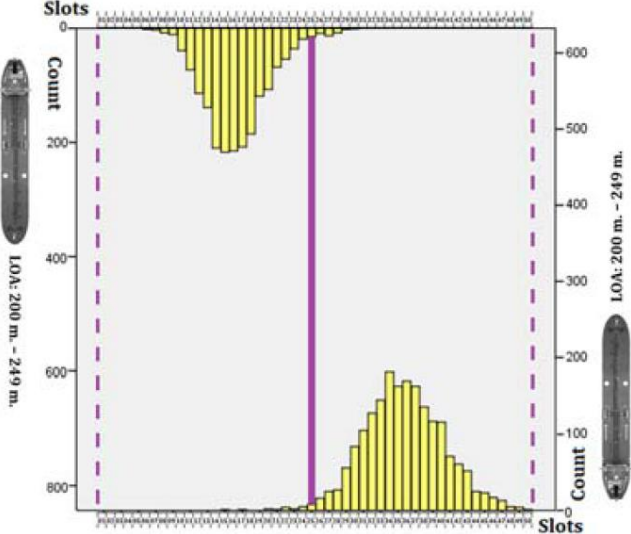

e) 200-249 meters

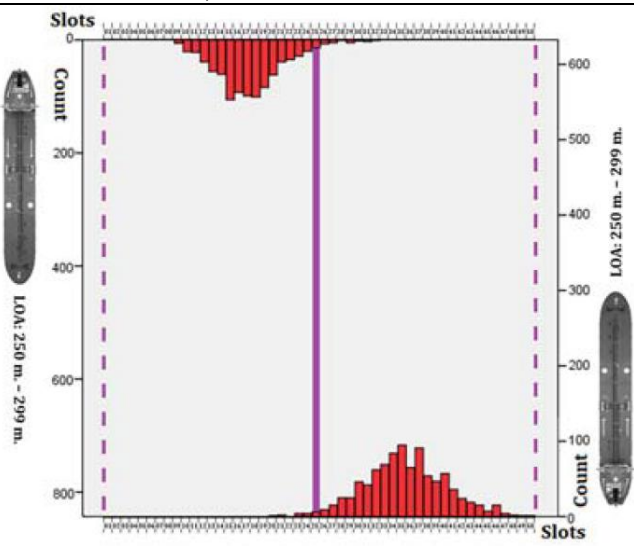

f) $250-299$ meters

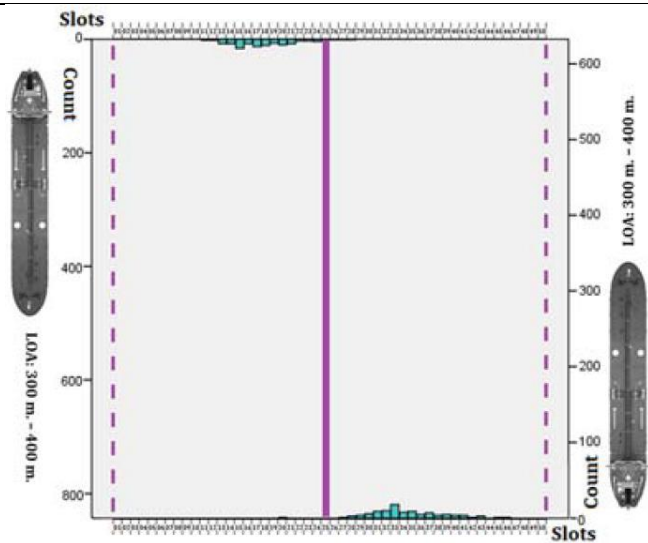

g) 300-400 meters

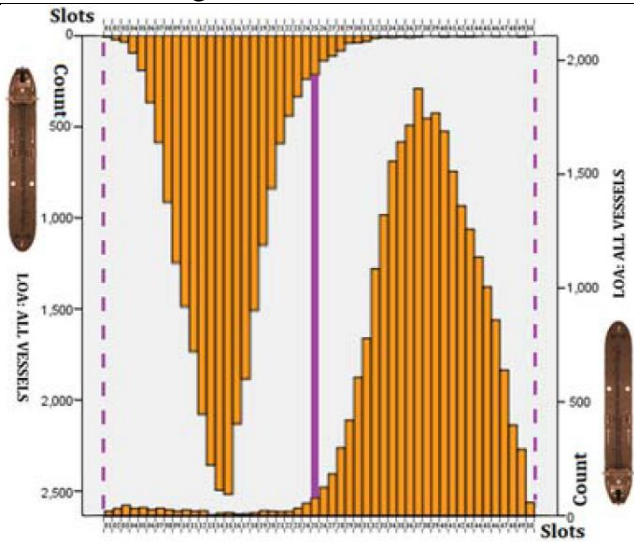

h) All vessels

Fig. 8. Distribution of the Vessels According to the LOA

Figure 6 shows the distribution of different types of vessels on the 1915 Çanakkale Bridge.
According to Figure 6, tankers seem to be less effected than cargo ships. It is also revealed in these distributions 
that the tankers and vessels with the lengths of 300 meters and above are mainly navigated in the middle of their traffic lane. In addition, it has been found that the average speed of tankers is higher than cargo ships. As a result, $18.59 \%$ of cargo ships, $11.37 \%$ of tanker ships, $3.74 \%$ of tanker ships larger than 200 meters, $1.82 \%$ of all types of ships larger than 300 meters and $18.92 \%$ of all ship traffic passing through the straits would be affected by the pillars of the 1915 Çanakkale Bridge and the safety distances of these towers but after the construction of the bridge and the establishment of the new TSS, the ships would adjust their voyage plan.

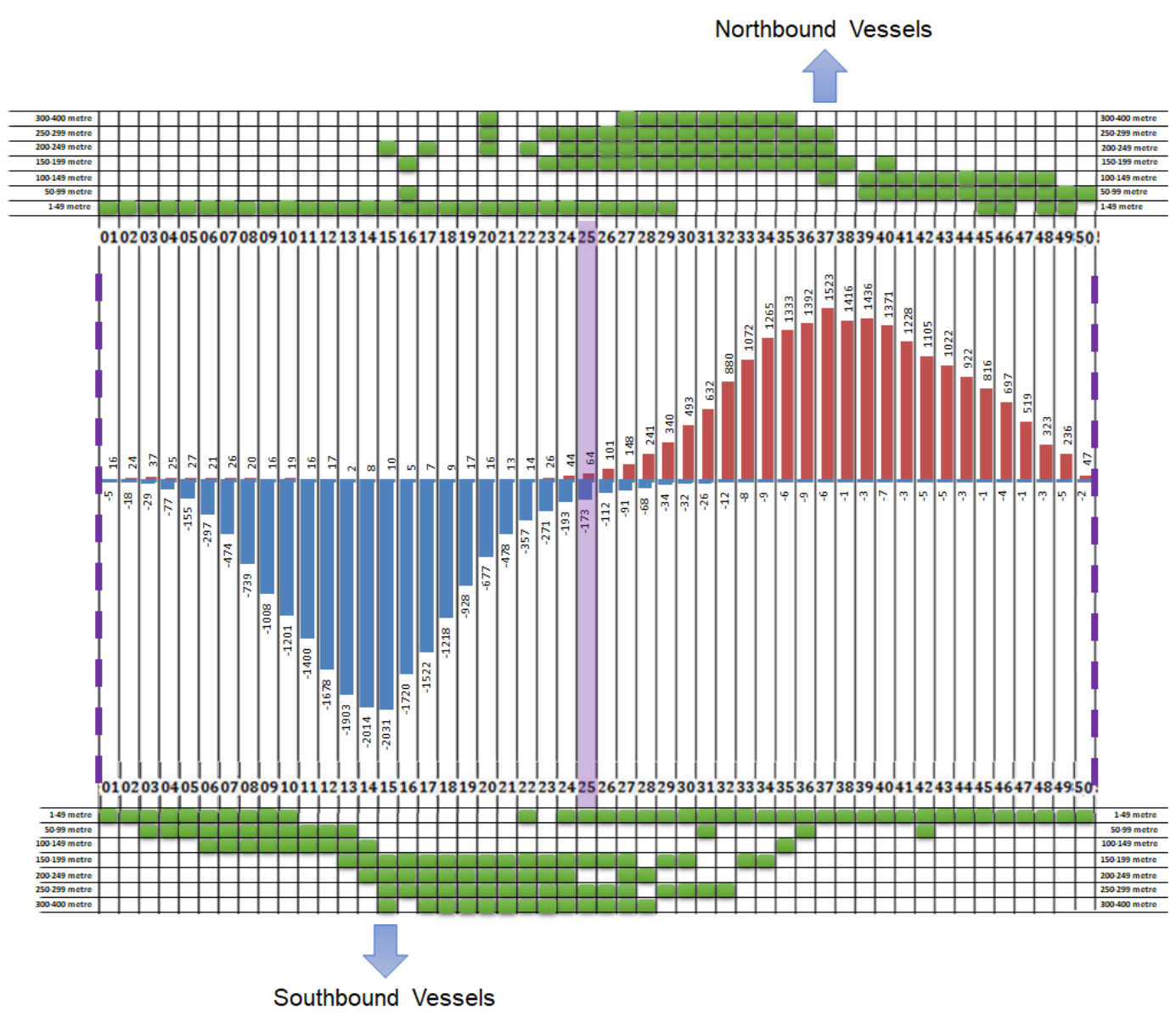

Fig. 9. Visualization of the Pearson Chi-square Test

According to the distribution of all types of vessels, average draft of the Northbound vessels are $6.63 \mathrm{~m}$ and average draft of the Southbound vessels are $6.62 \mathrm{~m}$. When the distribution of all types of vessels that have navigated through the Strait of Çanakkale in 2016 is investigated, it is assumed that the vessel distribution may follow the Gaussian distribution. To understand the vessel distribution on these cross-sectional lines, firstly, normality test has been carried out for Northbound and Southbound vessels separately. For the better and correct analysis results, vessel data on their own separation scheme has been taken into account. According to Table 1 , vessel distribution on the cross-sectional line does not fit with normal distribution in both directions. After the normality test, vessel distribution for different speed have been visualized. Figure 7 shows the distribution of the vessels according to the SOG. The vessels have been grouped as <8 knots, 8-9.9 knots, 10-11.9 knots, 12-13.9 knots, $>14$ knots. According to Figure 8 , it can be seen that different size of the vessels uses different slots. To understand the relation between the vessel sizes and their preferred slots, Pearson Chi-square test has been carried out. According to the analysis, there is a significant relationship (Northbound traffic $X^{2}(294)=8813.702^{a}$, $\mathrm{p}<0.001$ - Southbound traffic $\mathrm{X}^{2}(294)=6038.463^{\mathrm{a}}$, $\mathrm{p}<0.001)$ between the vessel sizes and preferred slots. The result of this test is visualized in Figure 9. According to the Pearson Chi-square test, if the actual number of the vessel is bigger than the expected number, the slots are filled by green colour. According to Figure 9 , it can be clearly seen that as the LOA of the vessels increases, the ships tend to move close to the middle of the separation scheme. The vessels with the length of between 1-49 i.e. the small vessels such as pleasure crafts, fishing vessels are not following the separation scheme rules.

Table 1. Normality Test

One-Sample Kolmogorov-Smirnov Test

\begin{tabular}{lr} 
& Northbound \\
N & 20622 \\
Asymp. Sig. (2-tailed) & $.000^{c}$ \\
\multicolumn{2}{c}{ One-Sample Kolmogorov-Smirnov Test }
\end{tabular}

Southbound

$\mathbf{N}$ 20566

Asymp. Sig. (2-tailed) 
While the average speed of the Northbound traffic is 11.04 knots (Sd: 2.634), the average speed of the Southbound traffic is determined as 12.06 knots ( $\mathrm{Sd}$ : 2.311). This speed difference is thought to be due to various reasons. The first and the most likely one is that; it is caused by currents from North to South in the Strait of Çanakkale. On the other hand, it is thought that this may be caused by the differences between the loaded conditions of the vessels in the Northbound and Southbound marine traffic. However, the reliability of the draught data is controversial due to the manual entry of draft values to the AIS device, and it is considered not reliable to make analysis on the relationship between draught and speed.

The seasonal analysis of the speed differences in the traffic separations, the speed distributions for each direction has been analyzed. As a result of the Normality Test on these speed distributions on the cross-sectional line, it is found that speed distributions do not fit with the normal distribution. For this reason, Kruskal-Wallis test has been performed to determine the differences between the speed averages for each direction according to the months. As a result of the test, it is found that the average speed in each traffic direction shows significant differences in months (Northbound traffic $X^{2}$ (11) $=291.896, \mathrm{p}<0.001)$ - South Bound traffic $X^{2}(11)$ $=125.815, \mathrm{p}<0.001)$.

For the detailed analyses, differences between the average ship speeds in months in the region are evaluated separately for each direction. Mann-Whitney $\mathrm{U}$ Test has been used to determine the differences between the average speed data on a seasonal basis. As a result of the analysis, it has been found that there is no significant difference $(p>0.05)$ between the speed averages in the winter and spring seasons for the Northbound vessel traffic, but there is a significant difference between the speed averages within the other seasons $(\mathrm{p}<0.001)$. Also, it has been found that there is no significant difference $(p>0.05)$ between the speed average in the spring and autumn seasons for the Southbound vessel traffic, but there is a significant difference between the speed averages within the other seasons $(p<0.001)$. Table 2 shows the average speeds of the vessels in months and seasons.

The average speed of Northbound vessel traffic is 11.04 knots, but it is less than the average in summer and autumn seasons (Summer:10.76 knots, Autumn:10.87 knots) and more than the average in winter and spring seasons (Winter:11.27 knots, Spring:11.28 knots). The average speed of the Southbound traffic is 12.06 knots, but it is more than the average in summer season $(12.30$ knots) and it is around average and below the average in winter and spring seasons (Winter:12.09 knots, Spring:11.98 knots, Autumn: 11.87 knots). All over the analyses, it is revealed that the currents towards the south direction assumed to be on the Strait of Çanakkale increases especially in summer and decreases in winter and spring seasons.

Table 2. Average Speeds of the Vessels according to the Months and Seasons

\begin{tabular}{|c|c|c|c|c|c|c|c|}
\hline \multicolumn{4}{|c|}{ Northbound Vessel Traffic } & \multicolumn{4}{|c|}{ Southbound Vessel Traffic } \\
\hline Months & $\begin{array}{l}\text { Average } \\
\text { SOG }\end{array}$ & Seasons & $\begin{array}{l}\text { Average } \\
\text { SOG }\end{array}$ & Months & Average SOG & Seasons & $\begin{array}{c}\text { Average } \\
\text { SOG }\end{array}$ \\
\hline 12 & 11.05 & & & 12 & 12.16 & & \\
\hline 1 & 11.47 & Winter & 11.29 & 1 & 12.02 & Winter & 12.08 \\
\hline 2 & 11.34 & & & 2 & 12.08 & & \\
\hline 3 & 11.39 & & & 3 & 12.06 & & \\
\hline 4 & 11.09 & Spring & 11.29 & 4 & 11.94 & Spring & 11.98 \\
\hline 5 & 11.38 & & & 5 & 11.95 & & \\
\hline 6 & 11.03 & & & 6 & 12.25 & & \\
\hline 7 & 10.75 & Summer & 10.77 & 7 & 12.26 & Summer & 12.30 \\
\hline 8 & 10.53 & & & 8 & 12.39 & & \\
\hline 9 & 10.61 & & & 9 & 11.77 & & \\
\hline 10 & 10.78 & Autumn & 10.88 & 10 & 12.13 & Autumn & 11.87 \\
\hline 11 & 11.26 & & & 11 & 11.70 & & \\
\hline
\end{tabular}

\section{Discussion and Conclusion}

This study is the first study in which traffic analysis is performed using AIS data in the Strait of Çanakkale. Essentially, the motivation of the study is the positioning of the towers of the 1915 Çanakkale Bridge at sea and this will create a navigational restriction. In addition to the determination of these restrictions, the vessel traffic characteristics on the cross-sectional line of the bridge are analysed.
According to the distribution of vessels on the crosssectional line, $18.59 \%$ of cargo ships, $11.37 \%$ of tanker ships, $3.74 \%$ of tanker ships larger than 200 meters and $18.92 \%$ of all ship traffic passing through the straits would be affected by the pillars of the 1915 Canakkale Bridge and the safety distances of these towers but after the construction of the bridge and the establishment of the new TSS, the ships would adjust their voyage plan. In order to determine the vessel traffic characteristics on the cross-sectional line, the line is divided into 50 slots of 50 meters each. It has been determined that the 
vessels are preferring to navigate on different slots according to their LOA. Also, it has been found that as the LOA of the ships increases, they tend to move port side of their traffic lane. In other words, as the vessel size gets smaller, they tend to move close to the starboard side of their traffic lane. Based on the newly developed separation scheme due to the construction of the bridge (Zorba \& Nas, 2019), it is predicted that the vessels that will prefer to navigate close to bridge towers will be small-sized vessels. It is considered that this prediction can be taken as a reference in the assessment of the risk of ship allision with bridge towers. For the safer navigation we also suggest to use Racon and sound signals on the bridge towers for restricted visibility. Also, we suggest a new VTS sector for this area to track the vessels in single window between Nara Point and Gelibolu. The bridge also be fitted with the navigation aids according to the IALA Navigation Manual (2014). Additionally, automatic AIS tracking system can be developed to warn VTS operator for abnormal ship movements. When the data of vessel traffic characteristics developed on the cross-sectional line are analyzed, distribution of the vessels does not fit with the normal distribution. In contrast, distribution of the vessels in Port of Rotterdam fit with normal distribution (Fangliang et al., 2012). According to the distribution of all types of vessels, average draft of the Northbound vessels are $6.63 \mathrm{~m}$. and average draft of the Southbound vessels are $6.62 \mathrm{~m}$. On the other hand, according to the VTS reported data for 2016, average draft of the Northbound vessels are $6.42 \mathrm{~m}$. and average draft of the Southbound vessels are $7.46 \mathrm{~m}$. This shows the inconsistency between the voyages related data manually entered into the AIS and the data reported to the VTS. As mentioned in the study conducted by (HaratiMokhtari et al., 2007), there might be some differences between the AIS data and the reported data from the vessels. Inconsistencies in the manually entered voyage related data create constraints for studies conducted by analyzing AIS data. It is also understood that current data can be deduced from the analysis of vessel traffic characteristics. Even in this study, it is revealed that information about seasonal changes in currents can be obtained. For further study, traffic characteristics with the different external conditions on this cross-sectional line may also be investigated like the study conducted by Shu et al. (2017).

\section{Acknowledgements}

This study was carried out by using the AIS data provided by the Republic of Turkey Ministry of Transport and Infrastructure General Directorate of Highways Public Private Sector Partnership to Dokuz Eylül University Maritime Faculty within the scope of the project dated 01.08.2017 and numbered 31/1.

\section{References}

Antonio, F. (1992). Faster Line Segment Intersection. In D. Kirk (Ed.), Graphics Gems III (p. 199). Academic Press, Inc.
Chen, J., Lu, F., Peng, G. (2015). A quantitative approach for delineating principal fairways of ship passages through a strait. Ocean Engineering, 103, 188-197. doi.10.1016/j.oceaneng.2015.04.077

Fangliang, X., Ligteringen, H., Gulijk, C. Van, \& Ale, B. (2012). AIS Data Analysis For Realistic Ship Traffic Simulation Model. Proceedings of IWNTM'2012.

Harati-Mokhtari, A., Wall, A., Brooks, P., \& Wang, J. (2007). Automatic Identification System (AIS): Data Reliability and Human Error Implications. Journal of Navigation, $\quad 60(3), \quad 373-389$, doi.10.1017/S037346330700429

IALA (2014) Aids to Navigation Manual. Seventh Edition, The International Association of Marine Aids to Navigation and Lighthouse Authorities

Ilgar, R. (2015). Çanakkale Boğazındaki gemi hareketliliği ve kaza risk haritasının belirlenmesi (Ship Mobility and Determination of Accident Risk Map in The Dardanelles). Türk Coğrafya Dergisi, 65, 1-10. doi.10.17211/tcd.73754

ITU-R. (2014). Technical characteristics for an automatic identification system using time division multiple access in the VHF maritime mobile frequency band. Electronic Publication.

Kang, L., Meng, Q., Liu, Q. (2018). Fundamental diagram of ship traffic in the Singapore Strait. Ocean Engineering, 147, 340-354., doi.10.1016/j.oceaneng.2017.10.051

Kuleyin, B., Aytekin, H. (2015). Çanakkale Boğazında 2004-2014 Yılları Arasında Gerçekleşen Deniz Kazalarının Analizi ve Kazaların Önlenmesine Yönelik Öneriler (Analysis of Marine Accidents Encountered at The Çanakkale Strait in Years Between 2004- 2014 And Recommendations Regarding the . Dokuz Eylül Üniversitesi Denizcilik Fakültesi Dergisi, 7(1), 21-38. doi.10.18613/deudfd.87984

Kundakçı, B., Nas, S. (2018). Mapping Marine Traffic Density by Using AIS Data: An Application in the Northern Aegean Sea. Polish Maritime Research, 25(4), 49-58. https://doi.org/10.2478/pomr-2018-0131

Liu, Z., Liu, J., Li, Z., Liu, R. W., and Xiong, N. (2017). Characteristics Analysis of Vessel Traffic Flow and Its Mathematical Model. Journal of Marine Science and Technology, 25(2), 230-241. doi.10.6119/ JMST-017-0109-1

Marcjan, K., Gucma, L., Voskamp, A. (2013). Vessel Traffic Stream Analysis in Vicinity of The Great Belt Bridge. In Marine Navigation and Safety of Sea Transportation (pp. 109-113). CRC Press. doi.10.1201/b14962-18

Mustaffa, M., Abas, M., Ahmad, S., Ahmad Aini, N., Abbas, W. F., Che Abdullah, S. A., Abd. Razak, N. I., Darus, M. Y. (2016). Marine Traffic Density Over Port Klang, Malaysia Using Statistical Analysis Of AIS Data: A Preliminary Study. Journal of ETA Maritime Science, 4(4), 333-341. doi.10.5505/ jems.2016.60352

Mustaffa, M., Ahmat, N. H., Ahmad, S. (2015). Mapping Vessel Path of Marine Traffic Density of Port Klang, Malaysia using Automatic Identification System ( AIS ) Data. International Journal of Science and Research (IJSR), 4(11), 245-248. 
Natale, F., Gibin, M., Alessandrini, A., Vespe, M., \& Paulrud, A. (2015). Mapping Fishing Effort through AIS Data. PLOS ONE, 10(6)., doi.10.1371/journal.pone.0130746

Shu, Y., Daamen, W., Ligteringen, H., \& Hoogendoorn, S. P. (2017). In fl uence of external conditions and vessel encounters on vessel behavior in ports and waterways using Automatic Identi fi cation System data. Ocean Engineering, 131(December 2016), 114, doi.10. 1016/j.oceaneng.2016.12.027

URL1. (2019). Republic of Turkey Ministry of Transport and Infrastructure, Maritime Statistics https://atlantis.udhb.gov.tr

Usluer, HB., Gazioğlu, C., Bora, AG. (2020). Simulation of Marine Pollution from a Tanker Accident at the Çanakkale Strait (Dardanelle), 6th International Conference on Environmental Science and Technology (ICOEST),

Wu, L., Xu, Y., Wang, Q., Wang, F., Xu, Z. (2017). Mapping Global Shipping Density from AIS Data. Journal of Navigation, 70(1), 67-81., doi.10.1017/S0373463316000345

Wu, X., Mehta, A. L., Zaloom, V. A., Craig, B. N. (2016). Analysis of waterway transportation in Southeast Texas waterway based on AIS data. Ocean Engineering, 121, 196-209. doi.10.1016/j.oceaneng.2016.05.012

Xiao, F., Ligteringen, H., van Gulijk, C., Ale, B. (2015). Comparison study on AIS data of ship traffic behavior. Ocean Engineering, 95, 84-93. doi.10.1016/j.oceaneng.2014.11.020

Zorba, Y., Nas, S. (2019). 1915 Çanakkale Köprüsü için Yeni Trafik Ayrım Düzeninin Değerlendirme Kriterlerinin Belirlenmesi ve Uygulanmas1 (Determination of Evaluation Criteria for the New Traffic Separation Schemes and Implementation for the 1915 Çanakkale Bridge). III. Global Conference on Innovation in Marine Technology and the Future of Maritime Transportation, April, 627-645. 